\title{
Indonesian Chinese'sCultural Behavior Represented in Indonesian Novels of Post Tragedy in 1998
}

\author{
Fatchul Mu'in \\ English Department of Lambung Mangkurat University, Banjarmasin-Indonesia
}

\begin{abstract}
This research is aimed at describing representation of IndonesianChinese'scultural behavior in the Indonesian novels of post tragegy in 1998. This discussion is conducted using (1) research procedure of sociology of literature, and (2) analysis model of Paul Recoeur's hermeneutics that works in three steps of semantic, reflective and existential levels. Data are derived from five Indonesian novelsThe selection of which are based on the purposive sampling technique. The representativeness of the novels and their authors is seen from the viewpoint and context of research object.This research is a descriptive-qualitative one for describing sociocultural phenomena. Data are analyzed based on the characteristics of cultural studies, through the process of identifying, classifying and analyzing data, interpreting and making a conclusion. The research results shows that personally Chinese faced a hard life; and socially they were dominated. Therefore, it can be concluded that: (1) the personal behaviour of Indonesian Chinese is represented through the hard life, (2) social behaviour of Indonesian Chinese is represented through the dominated social life, and (3) cultural behavior is represented through the religious life with many problems.This is say that the cultural behaviour of Indonesian Chinese in Indonesia novels belonging to post tragedy of 1998 is represented through cultural violence. Index terms: representation, Personal and social behavior, Indonesian Chinese, Indonesian novels
\end{abstract}

\section{INTRODUCTION}

Indonesian Chinese have contributed a lot of things in the development of Indonesian culture and civilization. In the field of literature, for example, many IndonesianChinese authors had produced literary works. Early Indonesian Literature (before Indonesian's independence) was colored by the presence of Chinese Malay literature. According to Salmon, the birth of the Chinese Malay literature was driven by movement of translation of Chinese novels into Malay by the Chinese authors (2010: 70). They had produced about 3,005 literary works. The two of them are stories Oey Se by Thio Tjien Boen, describing the adventures of a totokChinese becoming rich, and Lo Fen Koei by Gouw Peng Liang, telling the crime of a opium packter (Salmon, 2010: 375; Faruk et al. 2000: 13-14). Moreover, Santoso (2012: 61) states that the Chinese Malay literature is the milestone of literary history forgotten in the archipelago.

Indonesian Chinese literary authorship activity stalled. The cessation of activities of authorship was caused by a number of factors, among others: (1) the emergence of Balai Pustaka to control the reading material for society (Rukardi, 2010), (2) the strengthening of the Indonesian language as the national language in 1928, (3) an end of education separation for IndonesianChinese (Sumardjo, 2004: 2-3), and (4) prohibition against IndonesianChinese to express their culture in the era of New Order (Soyomukti, 2012: 203). The researches on literature with Indonesian Chinese'slife background were conducted by, among others: (1) Sainul Hermawan, (2005), which discussed the bad stigma of the Chinese in Indonesian Literature, (2) Alfiah Chusjairi (2005), which constructed Identity of Indonesian Chinesein Post New Order through the media, (3) Woodrich Christopher Allen (2011), which connected the tragedy of 1998 in the writing of novel Putri Cina (Princess of China), and (4) Kurniati Christina (2013), which examined the dynamics of the violence experienced byChinese women.

Researcheson Indonesianliterature relating to Indonesian Chinese culture have been carried out by a number of researchers. Both thoseresearches and this research are in relation to the issue of negative stereotypes of, violence experienced by, and exclusivity of Indonesian Chinese. While the differences in those researches form this one are in the caseof: the focus of study, literary works studied, ethnic background of the author, and the the theorical design and methods of research. Based on those differences, the research on the theme of cultural of IndonesianChinese in Indonesian novels can be regarded as a feasible new research. 


\section{RESEARCH METHODS}

This qualitative and descriptive research isaimed at analyzing the behavior of Indonesia Chinese through Indonesian novels. The research data are in the forms of words, phrases, sentences, or paragraphs indicating the social behavior of Indonesian Chinese. The data sources of this research are Indonesian novels, published after the tragedy of May 1998. The novels are selected using the purposive sampling technique with the considerations of the viewpoint and the context of the research object. The selected novels are presented in the tabel below.

Table 1. Data Resources

\begin{tabular}{|c|c|c|c|c|}
\hline $\mathrm{NO}$ & Titles of Novels & Authors & Publishers & Year \\
\hline 1 & Miss Lu & Naning Pranoto & Grasindo, Jakarta & 2003 \\
\hline 2 & $\begin{array}{l}\text { Putri Cina (Chinese } \\
\text { Girl) }\end{array}$ & Sindhunata & $\begin{array}{l}\text { PT } \\
\text { Jakarta }\end{array}$ & 2007 \\
\hline 3 & Bonsai & Pralampita & $\begin{array}{l}\text { PT } \quad \text { Gramedia, } \\
\text { Jakarta }\end{array}$ & 2011 \\
\hline 4 & $\begin{array}{l}\text { Pecinan (Chinese } \\
\text { Town) }\end{array}$ & $\begin{array}{l}\text { Ratna } \\
\text { Indraswari I. }\end{array}$ & Laksana, Yogyakarta & 2011 \\
\hline 5 & $\begin{array}{l}\text { Dimsum Terakhir } \\
\text { (The Last Dimsum) }\end{array}$ & Clara NG & $\begin{array}{l}\text { PT } \\
\text { Jakarta }\end{array}$ & 2012 \\
\hline
\end{tabular}

The five novels are the primary data sources. The supporting data sources are the novels of the similar theme, and reviews or Chinese studies.The data analysis is conducted based on the analysis of cultural studies. Referring to Winter (2014:253), this analysis starts fromdata collection up to the whole data of social behavior collected. Implementing Recoeur's analyzing stages (2012:221-223), data analysis is conducted in three stages, namely : semantic, reflexive, and existential stages to produce the emic holistic findings.

\section{RESULT AND DISCUSSION}

\section{A. Personal Behavior Work Ethic}

Indonesian Chinese have a high working ethics. The high working ethics are indicated by : (1) seriousness, (2) perseverance (3) hard work, and (4) never giving up (Putri Cina, p.74)

Tabel 2.Work Ethic

\begin{tabular}{|c|c|c|}
\hline $\begin{array}{l}\text { Behavioral } \\
\text { aspects }\end{array}$ & Behaviors in the novel & Behaviors represented \\
\hline Seriousness & $\begin{array}{l}\text { Keinginan menjadi peternak babi, tidak } \\
\text { selamanya menjadi buruh"Wanting to be } \\
\text { a pig farmer, not to be a coolie all the } \\
\text { time" (Bonsai, P. 27). } \\
\text { Berusaha untuk menabung"Trying to } \\
\text { save money" (Bonsai, P. 27). } \\
\text { Memulai usaha dengan sepasang } \\
\text { babi"Starting a business with a pair of } \\
\text { pigs" (Bonsai, P. 27). }\end{array}$ & $\begin{array}{l}\text { The character has the } \\
\text { desire to have his own } \\
\text { business, and he does not } \\
\text { want be dependent on } \\
\text { others. } \\
\text { Trying to raise capital, } \\
\text { Starting a business with a } \\
\text { small capital. }\end{array}$ \\
\hline Perseverance & $\begin{array}{l}\text { Mendatangi pembeli, bukan menunggu } \\
\text { pembeli"Going to the buyer, not waiting } \\
\text { for him/her" (Pecinan, P. 130) } \\
\text { Meningkatkan status dari penjual keliling } \\
\text { menjadi produsen."Improving the status } \\
\text { of a vendor to be a manufacturer" } \\
\text { (Pecinan, P. 130) }\end{array}$ & $\begin{array}{l}\text { Utilizing time optimally. } \\
\text { Ensuring a continuous } \\
\text { basis so that the business is } \\
\text { getting bigger and bigger }\end{array}$ \\
\hline $\begin{array}{l}\text { Working } \\
\text { hard }\end{array}$ & $\begin{array}{l}\text { Bekerja dengan memeras keringat } \\
\text { "Working with sweat" (Putri Cina, P. 74). } \\
\text { Bekerja tanpa kenal lelah"Working } \\
\text { tirelessly" (Putri Cina, P. 74). }\end{array}$ & Working mightily \\
\hline
\end{tabular}




\begin{tabular}{|l|l|l|}
\hline $\begin{array}{l}\text { Never giving } \\
\text { up }\end{array}$ & $\begin{array}{l}\text { Menekuni bidang peternakan } \\
\text { babi"Pursueing the field of pig farms" } \\
\text { (Bonsai, P. 27). }\end{array}$ & $\begin{array}{l}\text { Persisting in the certain } \\
\text { field of business. }\end{array}$ \\
$\begin{array}{l}\text { Mengembangkan usaha di bidang } \\
\text { produksi rokok"Developing business in } \\
\text { the production of cigarettes" (Pecinan, P. } \\
\text { 130). }\end{array}$ & \\
\hline
\end{tabular}

Table 2presents the meanings that (1) Boenarman, a character of the novel 'Bonsai', has a strong obsessionto possess his own business; he does not depend himself on the others to a collie. In relation to his obsession, he tries to collect a capital for developing his own business. Posessing his own capital, he will start his business using his small capital; (2) Lely's husband, a character of the novel 'Pecinan', utilizes his time optimally to work and strives continuously so that the business is getting bigger and bigger; (3) characters of the Novel 'Putri Cina'show their work hard; and since the beginning of Boenarman and Lely's, respectively pursue the field of animal husbandry and the production of cigarettes.

Indonesian Chinese are represented as people who have strong work ethic. Working in any work field, they are the serious, persevering, tireless and unyielding workers. Referring to Tjeng (1995: 164), the strong work ethic belonging to them has been affected by harsh climatic conditions in their origin country.

\section{Pride}

Individually, each of Indonedian Chinese has a pride for being the integral part of the ethnic group. He/she is proud of his/her family or clan, Chinese name, land and ancestral culture. The pride of Chineseness is presented in Table 3 as follows:

Table 3.Pride

\begin{tabular}{|l|l|l|}
\hline $\begin{array}{l}\text { Behavioral } \\
\text { aspects }\end{array}$ & Behaviors in the novel & Behaviors represented \\
\hline Pride & $\begin{array}{l}\text { Bangga akan marga Lu. "Being proud of the Lu } \\
\text { clan" (Miss Lu, p.6) }\end{array}$ & Being proud of the clan \\
\cline { 2 - 4 } & $\begin{array}{l}\text { Lebih memilih nama Tionghoa."Preferring the } \\
\text { Chinese name" (Dimsum Terakhir, p.206). }\end{array}$ & $\begin{array}{l}\text { Being proud of Chinese } \\
\text { name }\end{array}$ \\
\cline { 2 - 4 } & $\begin{array}{l}\text { Bangga akan tanah leluhur di Cina yang } \\
\text { subur."Being proud of fertile ancestral land in } \\
\text { China" (Miss Lu, p.6). }\end{array}$ & $\begin{array}{l}\text { Being proud of the } \\
\text { ancestral land pre }\end{array}$ \\
\cline { 2 - 4 } & $\begin{array}{l}\text { Tidak merelakan budaya leluhur diremehkan. } \\
\text { "Not willing their ancestral culture to be } \\
\text { underestimated". (Dimsum Terakhir, p.193). } \\
\text { Bangga akan nenek moyangnya yang menjadi } \\
\text { pembawa pembahauran dan peradaban."Being } \\
\text { proud of his ancestors who become the carriers of } \\
\text { renewal and civilization". (Putri Cina, p.32). }\end{array}$ & $\begin{array}{l}\text { Being proud of the } \\
\text { ancentral's gaits. }\end{array}$ \\
\hline
\end{tabular}

Table 3 presents the meanings that (1) a woman character on the novel Miss Lu prefers to be called Miss Lu, not Bella or Margareta; (2) Indonesian Chinese children have two names: Chinese and Indonesian names; (3) Miss Lu identifies herself dan her ancestors as Chinese and is proud of her ancestral land; her culture may not be underestimated; and (4) a woman character of Putri Cina declares that her ancestors have built civilization in Indonesian archipelago.

Indonesian Chinese are represented as the people whose ancentors had high culture and civilization. In the Dutch colonial era, they occupied the second highest position in the Indonesian archipelago. In relation to the pride of being Chinese people, they are proud of possessing the noble culture.

Culturally, Indonesian Chinese have an orientation to their ancentral culture and are proud of being Chinese. Hence, even if they are renamed with the Indonesian name, the name itself still implies the name, such as Liem Sioe Liong to be Sudono Salim in which Liem is similar to Salim. Sugiri adds that the Indonesian names selected stillshow proximity or similarity to their Chinese names (Sugiri, 2003: 68).

\section{Decison Making}

Indonesian Chinese can be said to be courageous in making decision. Their courage to make decisions occur when they go bankrupt in business or in a dilemmatic condition. They do not immerse themselves in unfavorable conditions. 
Table 4.Decision Making

\begin{tabular}{|c|c|c|}
\hline $\begin{array}{l}\text { Behavioral } \\
\text { aspects }\end{array}$ & Behaviors in the novel & Behaviors represented \\
\hline \multirow[t]{3}{*}{$\begin{array}{l}\text { Decision } \\
\text { making }\end{array}$} & $\begin{array}{l}\text { Memilih tinggal di luar negeri dengan } \\
\text { alasan keamanan dan keselamatan jiwa } \\
\text { "Choosing to live abroad for security } \\
\text { reasons and salvation of souls" (Pecinan, } \\
\text { p. 160-161) }\end{array}$ & $\begin{array}{l}\text { The Indonesian Chinese's political } \\
\text { attitude that must be conducted } \\
\text { when they werein unfavorable } \\
\text { conditions. }\end{array}$ \\
\hline & $\begin{array}{l}\text { Berpindah ke Singapura dengan alasan } \\
\text { negera ini menjamin kebebasan ekspresi } \\
\text { diri. "Moving to Singapore because this } \\
\text { country guarantees freedom of self- } \\
\text { expression"(Miss Lu, p.146). }\end{array}$ & $\begin{array}{l}\text { The Indonesian Chinese's attitude } \\
\text { that must taken when they ignored } \\
\text { the program of replacing the } \\
\text { personal names. }\end{array}$ \\
\hline & $\begin{array}{l}\text { Mengganti nama dari Wang Shu Zhua } \\
\text { menjadi Wahyudi Seputra karena ingin } \\
\text { menunjukkan nasinalisme Indonesia. } \\
\text { "Renaming Wang Shu Zhua to Wahyudi } \\
\text { Seputra because (he) wants to show his } \\
\text { nationalism of Indonesia" (Miss Lu, } \\
\text { p.146). }\end{array}$ & $\begin{array}{l}\text { The attitude of some Indonesian } \\
\text { Chinese in the program of } \\
\text { assimilation conducted by } \\
\text { Indonesian Government. }\end{array}$ \\
\hline
\end{tabular}

Table 4 presents the meanings of (1) the Indonesian Chinese's political attitude that must be conducted when they were in the unfavorable conditions; they decided immediatelyfor the sake of the salvation of their souls and assets; (2) the Indonesian Chinese's attitude that should be taken when there was an obligation for renaming the personal names; and (3) the Indonesian Chinese's attitude that should be taken when rejecting the assimilation program conducted by Indonesian Government.

Indonesian Chineseare represented as those who had very high courages tahat, among other things, can be viewed when (1) they take over the nationalized Dutch's large companies, (2) they (in particular, the middle class of IndonesianChinese) massively developed human capitalin the field of education, especially in technical and managerial skills, (3) the employers and other economic actors of IndonesianChinese made the investment, speculation, cooperative strategies and networking with the parties outside the country, (4) they had the closeness with the officialsthat causedthe collusion, corruption and nepotism. The fact shows that they bacame the target of the riots, as in Tregedy of May 1998. IndonesianChinesetraumatized by the violence, many of them decided to go abroad and move their capital to another country (Wulandari, 2011).

\section{Creativities in Business}

As we all know, the ability of the Indonesian Chinese to take advantage of the time and to see the business opportunity is indeed admirable. Even when most people think of a business in which there is no promising opportunity, with the perseverancethe Indonesian Chineseare able to convert a small chanceat first, to be the promising business fields (http://bisnisukm.com). Creativity in business is shown in the following table.

Table 5. Creativities in Business

\begin{tabular}{|c|c|c|}
\hline $\begin{array}{l}\text { Behavioral } \\
\text { aspects }\end{array}$ & Behaviors in the novel & Behaviors represented \\
\hline \multirow[t]{3}{*}{$\begin{array}{l}\text { Cretiavities in } \\
\text { business }\end{array}$} & $\begin{array}{l}\text { Ikut les menjahit dan bikin kue. } \\
\text { "Participating in a private lesson and } \\
\text { making a cake" (Pecinan, p.61). }\end{array}$ & Using the time optimally. \\
\hline & $\begin{array}{l}\text { Menjual cengkih dan rokok dengan } \\
\text { keliling di tempat yang baru. "Selling } \\
\text { cloves and cigarettes in new housing } \\
\text { environment" (Pecinan, p.130). }\end{array}$ & $\begin{array}{l}\text { Learning the } \\
\text { business in new housing } \\
\text { environment. }\end{array}$ \\
\hline & 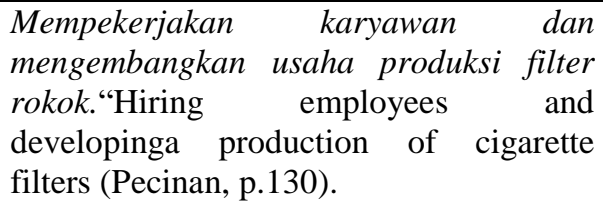 & $\begin{array}{l}\text { Developing a smal business into a } \\
\text { big one. }\end{array}$ \\
\hline
\end{tabular}

Table 5 gives the meanings of (1) the Indonesian Chinese really use the time optimally, (2) the Indonesian Chinese have the foresight to read a business opportunity. When they move to a new place, they make the 
observation toward a business world in their surrounding,and (3) the Indonesian Chinese do not feel satisfied to the available business. They will develop a small business into a big one.

Indonesian Chinese family is represented as the one that has a good ability of using the time to improve job skills, for example, letting the children to join courses in sewing and baking. Indonesian Chinesehave the ability to learn and take advantage of opportunities, and make decisions in certain circumstances, for example, when they succeed or fail. If they are successful in business, they plan to expand in other areas; however, if they fail in business, they immediately rise to improve their businesses or open other businesses.

\section{Assimilation}

In regard to assimilation, IndonesianChinese are classified into two groups. The first are those who receive the assimilation program, and the second are those who reject the assimilation program.

Table6.Assimilation

\begin{tabular}{|l|l|l|}
\hline $\begin{array}{l}\text { Behavioral } \\
\text { aspects }\end{array}$ & Behaviors in the novel & Behaviors represented \\
\hline Assimilation & $\begin{array}{l}\text { Lely, sekalipun dia lahir di Malang, tapi } \\
\text { keluarganya tidak begitu terikat erat dengan } \\
\text { budaya setempat. "Lely, even though she } \\
\text { was born in Malang, but her family is not so } \\
\text { closely tied to the local culture (Pecinan, } \\
\text { p.54) }\end{array}$ & $\begin{array}{l}\text { Rejecting the assimilation } \\
\text { to the local society. }\end{array}$ \\
\hline & $\begin{array}{l}\text { Keluarga Anggraeni sudah melakukan } \\
\text { kawin campur. "Anggraeni's family have } \\
\text { married to the persons of local community" } \\
\text { (Pecinan, p.12). }\end{array}$ & $\begin{array}{l}\text { Accepting the assimilation } \\
\text { through the mix marriage. }\end{array}$ \\
\hline $\begin{array}{l}\text { KeluargaAnggraeni sudah larut dalam } \\
\text { budaya setempat. "Anggraeni's familyhave } \\
\text { already dissolved in the local culture" } \\
\text { (Pecinan, p.12). }\end{array}$ & $\begin{array}{l}\text { Involving in the local } \\
\text { culture. }\end{array}$ \\
\hline
\end{tabular}

The Table 6 provides the following meanings. The Indonesian Chinese have been living and have made living in Indonesia and -up to the present time, recognize Indonesia as their homeland. Some of them refused to -but many of them-accept to assimilate to the local community. Culturally, they have conducted intermarriage and blended themselves into the local culture. They are still following the ancestral culture in one side of life; and at the same time they are also followingthe local culture. In fact, many people in general are having cultural experiencesfrom the IndonesianChinese community.

Viewed from the perspective of the origin country, they came from the different areas. Viewed from the perspective of orientation toward ancestral culture, there are TotokChineseand Peranakan Chinese. TotokChinesehave a strong orientation toward the ancestral culture and identify themselves as citizens of China; while Peranakan Chinese have declared themselves as the citizens of Indonesia. From a cultural perspective, Peranakan Chinesehavealso showed their cultural heterogeneities (Vasanty, 1984:348; Suryadinata, 2002:17). Most of the Peranakan Chinesehave assimilated tothe local community; some others still have orientation to their ancentral culture.

\section{Apolitical Attitude}

This apolitical attitude is related to the political orientation in the past time, which then leads the the stereotype of "Tionghoa atau Cina dianggap bagian dari komunis" ("Chinese are considered a part of the communists") although not all of them are the communists. As a result, today there is a feeling of fear among Indonesia Chinese community to take a part in the politicall affairs of this Indonesian nation. This is shown by the statement : "Papimu itu suka bermimpi. Aku tidak suka dia ngomong politik. Jangankan jadi walikota, jadi kepala desa saja sulit kalau keturunan Cina. Sebaiknya, kamu belajar dari Lely. Hidup sebagai keturunan perantau Cina, tidak perlu bermimpi menjadi pahlawan"(Your father likes to dream. I do not like him to talk politics. Let alone becomea mayor, to become the village head is hard to achieve for the Chinese descendant. I recommend that you may learn from Lely. Life as a descendant of Chinese immigrants, it is not necessary dreaming of becoming a hero) (Pecinan, p. 62).

The data show that the mother of Anggraeni have disliked political stance. She wanted her family not to involve in the political affairs. She realized that the Indonesian Chinesefaced many difficulties to be the government officials. 


\section{Feeling of Superiority}

Initially, the indigenous people and Indonesian Chinese lived in peace, harmony and side by side. They blended into and enrichedthe indigenous culture. The living condition turned into its opposite. This living condition can be seen in the following table.

Tabel 7. Feeling of Superiority

\begin{tabular}{|c|c|c|}
\hline $\begin{array}{l}\text { Behavioral } \\
\text { aspects }\end{array}$ & Behaviors in the novel & Behaviors represented \\
\hline \multirow[t]{3}{*}{$\begin{array}{l}\text { Feeling of } \\
\text { Superiority }\end{array}$} & $\begin{array}{l}\text { Kompeni menjunjung orang-orang Cina } \\
\text { secara istimewa. "Dutch's company upholds } \\
\text { the Chinese in a special way"(Putri Cina, } \\
\text { p.105). }\end{array}$ & $\begin{array}{l}\text { Having higher social position } \\
\text { than native people. }\end{array}$ \\
\hline & $\begin{array}{l}\text { Kelihatan berbeda dan lebih daripada kaum } \\
\text { pribumi. "They seem to be different and to } \\
\text { have higher social position that the native } \\
\text { Indonesia" (Putri Cina, p.105). }\end{array}$ & $\begin{array}{l}\text { Living separatedly } \text { from } \\
\text { native people. }\end{array}$ \\
\hline & $\begin{array}{l}\text { Memandang rendah martabat orang Jawa. } \\
\text { "They (IndonesianChinese) look down on } \\
\text { Javanese people" (Pecinan, p. 61) }\end{array}$ & $\begin{array}{l}\text { Underestimating the other } \\
\text { ethnic groups. }\end{array}$ \\
\hline
\end{tabular}

The superior attitude of Indonesian Chinese was a result of the treatment given in Dutch colonial era.The Dutch positioned them at a higher social stratification and separated the residence from the indigenous community. These social treatments resulted in superior attitude for Indonesian Chinese.

Sociological studies among the Indonesian Chinese in Java have confirmed that in general the IndonesianChinese have been regarded as being higher in terms of ability, intelligence, and energythan native Indonesian people. Superior feeling is closely related to the fact that in the past time Indonesian had the higher socio-economic position than that of native Indonesian people. Unless the Indonesian Chinese are poor, in general, they have at least one household assisstant from the native people (Coppel, 1994: 44).

Ambivalence, Mimicry dan Hybrid

Living in Indonesian archipelago, the Indonesian Chinese immigrants have behaviors of hybridity, mimicry, and ambivalence. These are shown in the following table:

Table 8. Hybridity, mimicry, and ambivalence

\begin{tabular}{|l|l|l|}
\hline $\begin{array}{l}\text { Behavioral } \\
\text { aspects }\end{array}$ & Behaviors in the novel & Behaviors represented \\
\hline Hybridity & $\begin{array}{l}\text { Larut dalam budaya setempat. "Adopting the } \\
\text { local culture" (Pecinan, p. 12). } \\
\text { Menjadi pemain ketoprak. "Becoming a player } \\
\text { of Ketoprak (traditional Javanese drama)" (Putri } \\
\text { Cina, p. 158). } \\
\text { Merasa menjadi anak Jawa. "Identifying herself } \\
\text { as a Javanese child" (Miss Lu, p. 136). }\end{array}$ & $\begin{array}{l}\text { Parcipating in the local } \\
\text { Mimicry }\end{array}$ \\
$\begin{array}{l}\text { Pada era Belanda, memihak kepada Belanda } \\
\text { karena akan memberikan fasilitas kepada etnik } \\
\text { Tionghoa. "In the colonialism era of Dutch, } \\
\text { Indonesian Chinese sided with Dutch because of } \\
\text { facilities" (Miss Lu, p. 139). }\end{array}$ & Opportunist \\
\hline Ambivalence & $\begin{array}{l}\text { Mencintai Indonesia sebagai bagian dari } \\
\text { kehidupannya tetapi tidak bersedia mengikuti } \\
\text { program asimilasi. "[Miss Lu] loves Indonesia } \\
\text { as a part of her life, but she is not willing to } \\
\text { attend the assimilation program" (Miss Lu, p. } \\
\text { 147). }\end{array}$ & Loving and hating at the \\
\hline
\end{tabular}

Representation of these attitudes can be understood through a historical view. In the days before the advent of colonial Dutch, IndonesianChinese have long coexisted with the indigenous communities. Indonesian Chinesebecame a community positioning between Dutch and the indigenous communities. When the Dutch gave some advantages, they lived by side of the Dutch, and took a socialdistance from the natives. At the time of independence, the IndonesianChineselost their second social position. Most were willing to become Indonesian 
citizens; the others oriented to their native land. Ambivalence occured, namely they loved Indonesia and also loved their native country, and loving and hating Indonesia at the same time.

\section{B. Social Behaviors \\ In-group social behaviors}

Behavior in Indonesian Chinese's family environment presented here is behavior in choosing a mate and treating a woman. These types of behavior are presented in the following table.

Table 9.Behavior in Family Environment

\begin{tabular}{|c|c|c|}
\hline $\begin{array}{l}\text { Behavioral } \\
\text { aspects }\end{array}$ & Behaviors in the novel & Behaviors represented \\
\hline $\begin{array}{l}\text { Looking for } \\
\text { husband for } \\
\text { girl }\end{array}$ & $\begin{array}{l}\text { Menolak keluarga penjudi. } \\
\text { "Ignoring (a husband) from the } \\
\text { family of gambler" (Pecinan, p. } \\
\text { 73) } \\
\text { Menolak keluarga baba. } \\
\text { "Ignoring (a husband) from the } \\
\text { Baba family" (Pecinan, p. 73) } \\
\text { Menolak pemalas. "Ignoring the } \\
\text { lazy man" (Pecinan, p. 73) }\end{array}$ & $\begin{array}{l}\text { Choosing a man from the respectable } \\
\text { family. } \\
\text { Choosing a man from the same clan. } \\
\text { Choosing a tenacious man in working. }\end{array}$ \\
\hline $\begin{array}{l}\text { Positioning } \\
\text { women }\end{array}$ & $\begin{array}{l}\text { Meminggirkan perempuan. } \\
\text { "Marginalyzing } \\
\text { wemen. } \\
\text { Tidak diperbolehkan mengenal } \\
\text { dunia luar. "[Girls] are not } \\
\text { allowed to recognize the outside } \\
\text { community" (Pecinan, p. 15) } \\
\text { Diberi fasilitas yang berbeda } \\
\text { dengan anak laki-laki. [Girls] } \\
\text { are given different facilities } \\
\text { from sons" (Pecinan, p. 15) } \\
\text { Hidup dalam kepasrahan. [Putri } \\
\text { Cina] lives in a resigned } \\
\text { condition"(Putri Cina, p.120) }\end{array}$ & $\begin{array}{l}\text { Positioning women in the second } \\
\text { social class after men. } \\
\text { Limiting the girl in establishing } \\
\text { relationship with wider community. } \\
\text { Giving the different treatments from } \\
\text { the sons to the daughters. } \\
\text { The girls (women) are powerless. }\end{array}$ \\
\hline
\end{tabular}

Table 9 presents the meanings that the IndonesianChinese (1) put women at the second social position after the men, (2) limit the girls in establishing relationship with wider community, (3) provide different treatments from sons to daughters, and (4) Chinese women are in a powerless position. Boys are expected to preserve the Chinese tradition. In a family environment, Indonesian Chinese women are treated differently from men. In a riot situation, they are very vulnerable to sexual violence.

Social relations built by the Indonesian Chinese is the relationship among them. Beliefs and moral teachings of Taoism, Confucianism, and Buddhism has taught the harmonious relationship among members of the family and the relationships within the community.

Tabel 10. In-group social relationship

\begin{tabular}{|c|c|c|}
\hline $\begin{array}{l}\text { Behavioral } \\
\text { aspects }\end{array}$ & Behaviors in the novel & Behaviors represented \\
\hline $\begin{array}{l}\text { Behavior in } \\
\text { group }\end{array}$ & $\begin{array}{l}\text { Papa ditampung oleh seorang } \\
\text { Tionghoa totok bernama Tan Dhie- } \\
\text { Oeng. "Father was recruited by } \\
\text { Totok Chinese named Tan Dhie- } \\
\text { Oeng" (Pecinan, p. 9). }\end{array}$ & $\begin{array}{l}\text { Chinese whose economic } \\
\text { condition has been well- } \\
\text { established help their fellow } \\
\text { Chinese. }\end{array}$ \\
\hline $\begin{array}{l}\text { Behavior in } \\
\text { business }\end{array}$ & $\begin{array}{l}\text { Megembangkan usaha untuk } \\
\text { kepentingan sesama Tionghoa. } \\
\text { "[They] develop business for the } \\
\text { sake of their fellow Chinese" } \\
\text { (Pecinan, p. 9). }\end{array}$ & $\begin{array}{l}\text { They have solidarity among } \\
\text { them. }\end{array}$ \\
\hline $\begin{array}{l}\text { Behavior in } \\
\text { political }\end{array}$ & $\begin{array}{l}\text { Aku tidak suka dia ngomong } \\
\text { politik."I don't like him talking }\end{array}$ & $\begin{array}{l}\text { [Father] wants to involve in } \\
\text { political affairs. }\end{array}$ \\
\hline
\end{tabular}




\begin{tabular}{|l|l|l|}
\hline affairs & $\begin{array}{l}\text { about political affairs" (Pecinan, p. } \\
\text { 62). }\end{array}$ & \\
\hline & $\begin{array}{l}\text { k.jadi kepala desa saja sulit kalau } \\
\text { keturunan Cina. "Becoming a head } \\
\text { of village is a difficult matter for the } \\
\text { Chinese descent (Pecinan, p. 62). }\end{array}$ & $\begin{array}{l}\text { [Some] want some others } \\
\text { not to take a part in political } \\
\text { affairs. }\end{array}$ \\
\hline
\end{tabular}

The data present the meaning that (1) Indonesian Chinese help people of their ethnic group who have not had economic ability to live, (2) they educate their children to have business, (3) they have high solidarity toward people of their ethnic group, (4) they have two views in political affairs: involving in political affairs and having political view to avoid political affairs and to prefer to develop their business.

Out-Group Social Behaviors (Native Indonesian- Indonesian Chinese)

This part presents out-group social behaviors (native Indonesian-Indonesian Chinese), that covers (1) social relationship, (2) business relationship, (3) marriage relationship, and (4) political activities.

Table 11. Out-Group Social Behaviors (Native Indonesian- Indonesian Chinese)

\begin{tabular}{|l|l|l|}
\hline $\begin{array}{l}\text { Behavioral } \\
\text { aspects }\end{array}$ & Behaviors in the novel & Behaviors represented \\
\hline $\begin{array}{l}\text { Social } \\
\text { relationship } \\
\text { between two } \\
\text { ethnic } \\
\text { groups }\end{array}$ & $\begin{array}{l}\text { oma saya dapat banyak teman di Sidoarjo } \\
\ldots . \text { bukan kalangan orang Cina. Anak-anak } \\
\text { Jawa. "My grand mother have many friends } \\
\text { in Sidoarjo... not from Indonesian Chinese } \\
\text { community"(Miss Lu, p. 136) }\end{array}$ & $\begin{array}{l}\text { [Indonesian Chinese woman] } \\
\text { made friends with the native } \\
\text { Indonesian children. }\end{array}$ \\
\hline $\begin{array}{l}\text { Business } \\
\text { relationship }\end{array}$ & $\begin{array}{l}\text { Ia menciptakan lahan usaha untuk orang- } \\
\text { orang pribumi dari kalangan bawah-wong } \\
\text { cilik, oma saya bilang. "She opens the field } \\
\text { of jobs for the native people from the poor } \\
\text { communities, my grandma said" (Miss Lu, p. } \\
\text { 144) }\end{array}$ & $\begin{array}{l}\text { [Indonesian Chinese woman] } \\
\text { opened the field of jobs for } \\
\text { the native Indonesian people. }\end{array}$ \\
\hline $\begin{array}{l}\text { Marriage } \\
\text { relationship }\end{array}$ & $\begin{array}{l}\text { Sudah kawin campur"....[they] involved } \\
\text { herself in the local culture, conducting } \\
\text { intermarriage" (Pecinan, p. 12)...menikah } \\
\text { dengan Rahman, orang Jawa. "[An } \\
\text { Indonesian Chinese woman] got married to } \\
\text { Rahman, a Javenese person"(Pecinan, p. 21). }\end{array}$ & $\begin{array}{l}\text { [Indonesian Chinese woman } \\
\text { conducted intermarriage. }\end{array}$ \\
\hline $\begin{array}{l}\text { Political } \\
\text { activities }\end{array}$ & $\begin{array}{l}\text { Aku tidak suka dia ngomong politik. “ I } \\
\text { didn't like him talking about political affairs" } \\
\text { (Pecinan, p. 62). }\end{array}$ & $\begin{array}{l}\text { [Some Indonesian Chinese } \\
\text { did not want the others to } \\
\text { involve in the political } \\
\text { affairs. }\end{array}$ \\
\hline
\end{tabular}

The data present the meanings that (1) in human relationship, Indonesian Chinese establish social relationship to the native people, (2) in business, they need workers from both their ethnic group and the native people, (3) involving the native people is their business strategy to develop their business in the village or subdistrict areas.Also, the data present the meanings that (1) some Indonesian Chinese get married to the native people and some others avoid marrying the native people.

Also, the data serve the meaning that Indonesian Chinese have the various political behaviors : (1) some oriented to their ancentral country, (2) some oriented to Republic of Indonesia, and some others are ambivalent, and some avoid the political affairs.

\section{Consequences of In-Group and Out-Group Social Relationships}

There are some consequences of in-group and out-group social relationships. The beheviors represented are served in the following table. 
Table 12. Behaviors as a Result of Sterotype, Prejudice, and Discrimination

\begin{tabular}{|c|c|c|}
\hline $\begin{array}{l}\text { Behavioral } \\
\text { aspects }\end{array}$ & Behaviors in the novel & $\begin{array}{l}\text { Behaviors } \\
\text { represented }\end{array}$ \\
\hline \multirow{5}{*}{$\begin{array}{l}\text { Facing } \\
\text { negative } \\
\text { stereotype }\end{array}$} & $\begin{array}{lcr}\text { (Diakui bahwa) } & \text { mereka } & \text { sangat } \\
\text { eksklusif“They } & \text { are } & \text { excluvely } \\
\text { living”(Pecinan, p. 221) } & \\
\end{array}$ & Living exclusively \\
\hline & $\begin{array}{l}\text { (Dibantah bahwa) opa saya jelas-jelas } \\
\text { bukan komunis, walau ia berdarah } \\
\text { Cina. "My grandma is actually not a } \\
\text { communist"(Miss Lu, p.149). }\end{array}$ & \begin{tabular}{lr}
\multicolumn{2}{l}{ Being communists or } \\
having a close \\
relatioship \\
Cummunism.
\end{tabular} \\
\hline & $\begin{array}{l}\text { (Diakui bahwa) Tergila-gila akan } \\
\text { dagangjuga tak bisa disalahkan pada } \\
\text { orang Cina. "Loving business cannot } \\
\text { only directed to Indonesia Chinese" (Putri } \\
\text { Cina, p. 80). }\end{array}$ & $\begin{array}{l}\text { Being economic } \\
\text { animals. }\end{array}$ \\
\hline & $\begin{array}{l}\text { (Dibantah karena) Mereka juga lebih } \\
\text { menguasai bahasa Indonesia daripada } \\
\text { bahasa Mandarin. "They have a mastery } \\
\text { of Indonesian language more than } \\
\text { Chinese one" (Dimsum, p. 134) }\end{array}$ & $\begin{array}{l}\text { Being contra- } \\
\text { nationalists. }\end{array}$ \\
\hline & $\begin{array}{l}\text { (Dibantah karena di antara) Mereka } \\
\text { menjadi tukang kayu, tukang batu, } \\
\text { pandai besi, bahkan juga banyak yang } \\
\text { masih menjadi kuli, yangsemiskin kaum } \\
\text { pribumi. "They become carpenters, } \\
\text { masons, blacksmiths, even many are still } \\
\text { coolies, which are as poor as the native } \\
\text { people"(Putri Cina, p. 105). }\end{array}$ & $\begin{array}{l}\text { Being regarded as the } \\
\text { rich people. }\end{array}$ \\
\hline Prejudice & $\begin{array}{l}\text { (Dianggap) Jadi biang keladi kekacauan } \\
\text { di Pedang Kemulan ini adalah orang- } \\
\text { orang Cina. "They were regarded as the } \\
\text { main causes of chaos in Pedang } \\
\text { Kemulan"(Putri Cina, p. 150). }\end{array}$ & $\begin{array}{l}\text { There is a hatred } \\
\text { attitude } \\
\text { Indonesian Chinese. }\end{array}$ \\
\hline Discrimination & $\begin{array}{l}\text { (Bila tidak mau menjadi warga negara } \\
\text { Indonesia), mereka harus kembali ke } \\
\text { Cina. "Ignoring to be Indonesia citizens } \\
\text { means they must go back to China"(Miss } \\
\text { Lu, p. 137). } \\
\text { Pemerintah Soekarno tidak } \\
\text { memperbolehkan seseorang punya dua } \\
\text { kewarganegaraan. "Soekarno's } \\
\text { Government did not allow anyone having } \\
\text { two citizenships" Miss Lu, p.137). }\end{array}$ & $\begin{array}{l}\text { There was a different } \\
\text { treatment in law. }\end{array}$ \\
\hline & $\begin{array}{l}\text { (Orang Tionghoa)Sulit } \text { bekerja di } \\
\text { lembaga pemerintahan" Indonesian } \\
\text { Chinese were hard to get jobs in the } \\
\text { governmental institution" (Pecinan, p. } \\
\text { 57). }\end{array}$ & $\begin{array}{l}\text { Politically, there was } \\
\text { a different treatment } \\
\text { in the job formation } \\
\text { for the goverment's } \\
\text { officers. }\end{array}$ \\
\hline & $\begin{array}{l}\text { Dilarang berdagang di kota kecamatan } \\
\text { dan kota kabupaten. Orang Cina hanya } \\
\text { boleh berdagang di kota-kota besar" } \\
\text { Penguasa menggaet para pengusaha } \\
\text { besar Cina buat bekerja sama, yang } \\
\text { dalam prakteknya malah dijadikan sapi } \\
\text { perah mereka. "The Indonesian Chinese } \\
\text { businessmen were banned to trade in the } \\
\text { centre of subdistrict and country town" } \\
\text { (Putri Cina, p. 144). }\end{array}$ & $\begin{array}{l}\text { Economically, there } \\
\text { was a different } \\
\text { treatment in trading. }\end{array}$ \\
\hline & Sekolah Tionghoa ditutup dan diambil & In educ \\
\hline
\end{tabular}




\begin{tabular}{|l|l|l|}
\hline alih. "Indonesian Chinese Schools were & there was a different \\
closed and taken over"(Pecinan, p. 44). & treatment for \\
Tampang Cina tapi tidak mampu & Indonesian Chinese \\
berbahasa Cina, sudah pasti orang & to socio-cultural \\
Indonesia (karena tidak memiliki & affairs. \\
kesempatan belajar bahasa Cina). & \\
"Having Chinese performance but not & \\
having ability to speak Chinese must be & \\
Indonesian Chinese (because of not & \\
having opportunity to learn Chinese & \\
language" (Dimsum Terakhir,p. 86). & \\
\hline
\end{tabular}

In relation to the aspect of stereotypes, the data presentation give the meanings that (1) the IndonesianChineselive exclusively. The impression that they live exclusively is uncontested because the facts existing in the wider community shows that they live in groups. The area where they live is often called Chinatown; (2) every Indonesian Chinese person is regarded as a communist or has a close relation to communism. Identification through generalization implies that all IndonesianChinese are communists or have a close relation to communism. Then the stereotypes are denied, that not all Indonesian Chinese are communists; (3) the Indonesian Chinese accept the stereotypesas economic animals and treasure lovers. The way they have taken to get the treasure is the trade. Through the trade, they accumulate wealth that bring them into the wealthy; and (4) some have principle to be fully Indonesian people, and some others want to be Indonesian people and at the same time to be Chinese. Assimilation program launched by the government is neglected. They are not willing to change their names from Chineseto the Indonesian ones.

Furthermore, Indonesian Chinese have the problems of residential segregation, violence, robbery, rape, expulsion and murder, as summarized in the following table.

Table 12. Behaviors resulted from dominative condition

\begin{tabular}{|c|c|c|}
\hline $\begin{array}{l}\text { Behavioral } \\
\text { aspects }\end{array}$ & Behaviors in the novel & $\begin{array}{l}\text { Behaviors } \\
\text { represented }\end{array}$ \\
\hline Segregation & $\begin{array}{l}\text { Tempat tinggal mereka pun dipisahkan dari } \\
\text { penduduk pribumi, supaya mereka kelihatan } \\
\text { berbeda dan lebih tinggi daripada kaum } \\
\text { pribumi. "Their houses were also segregated } \\
\text { from the native indonesian community, in } \\
\text { order that they looked different from and } \\
\text { higher than the native ones" (Putri Cina,105) }\end{array}$ & $\begin{array}{l}\text { Segregation } \\
\text { Indonesian } \\
\text { community from the } \\
\text { native one. }\end{array}$ \\
\hline Violence & $\begin{array}{l}\text { Mereka (pribumi) menyerbupermukiman } \\
\text { orang-orang Cina, menjarah hartanya, dan } \\
\text { membantainya."They (native Indonesian } \\
\text { people) raided the settlement of the } \\
\text { Indonesian Chinese, looted their property, and } \\
\text { slaughtered them" (Putri Cina, 107). } \\
\text { Bila pertikaian itu pecah, maka dia dan } \\
\text { kaumnyalah yang } \\
\text { korbannya."When the riot broke out, she } \\
\text { [Putri Cina] and her people were the } \\
\text { victim"(Putri Cina, 124). }\end{array}$ & 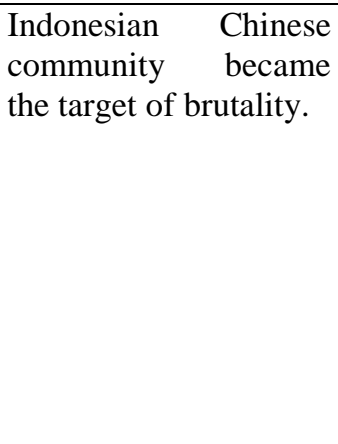 \\
\hline Robbery & $\begin{array}{l}\text { Harta mereka dijarah. Rumah-rumah mereka } \\
\text { dibakar. Tempat-tempat berdagang mereka } \\
\text { dibumihanguskan."Their property was looted. } \\
\text { Their houses were burned. Their trade center } \\
\text { was burned down"(Putri Cina, 150). }\end{array}$ & $\begin{array}{l}\text { They became the } \\
\text { target of looting and } \\
\text { robbery. }\end{array}$ \\
\hline Rape & $\begin{array}{l}\text { Ketika akhirnya terpegang, para lelaki itu } \\
\text { dengan beringas menelanjangi wanita-wanita } \\
\text { Cina itu, merebahkan mereka, dan } \\
\text { melampiaskan nafsu mereka, sepuas- } \\
\text { puasnya."When she was finally held in check, } \\
\text { the man violently stripped the Indonesia } \\
\text { Chinese women, laid them, and lusted heart's }\end{array}$ & $\begin{array}{l}\text { Indonesian Chinese } \\
\text { women became the } \\
\text { target of rape. }\end{array}$ \\
\hline
\end{tabular}




\begin{tabular}{|c|c|c|}
\hline & $\begin{array}{l}\text { content up to the point of satisfaction"(Putri } \\
\text { Cina, 119). }\end{array}$ & \\
\hline Expulsion & $\begin{array}{l}\text { Malah mereka mengusir sebagian orang } \\
\text { orang Cina dari Batavia. Banyak orang Cina } \\
\text { waktu itu terpaksa pulang ke Negeri Cina. } \\
\text { "Instead, they drove some Indonesian } \\
\text { Chinese from Batavia. At that time, many } \\
\text { Indonesian Chinesewere forced to return to } \\
\text { the Land of China" (Putri Cina, 106). } \\
\text {...orang Cina, dilarang berdagang di kota } \\
\text { kecamatan dan kota kabupaten. Orang Cina } \\
\text { hanya boleh berdagang di kota-kota besar. } \\
\text { "IndonesianChinesetraders were banned to } \\
\text { trade in the centres of subdistricts and country } \\
\text { towns. They were only allowed to trade in big } \\
\text { cities"(Miss Lu, 144). } \\
\text { Mereka memilih tinggal di luar negeri. } \\
\text { Itulah plihan paling realistis. "They prefered } \\
\text { to live abroad. That was the realistic } \\
\text { preference" (Pecinan, 161). }\end{array}$ & $\begin{array}{l}\text { In the past time, } \\
\text { Indonesia Chinese } \\
\text { contrary to Dutch had } \\
\text { been forced to move } \\
\text { from Batavia; in the } \\
\text { early period of } \\
\text { Indonesian } \\
\text { Independence, they are } \\
\text { forbidden to trade in } \\
\text { the centres of small } \\
\text { towns; and in the } \\
\text { unsafe condition, they } \\
\text { will prefer to move } \\
\text { and to live abroad. }\end{array}$ \\
\hline Mur & $\begin{array}{l}\text { mayat-mayat orang Cina bergelimpangan di } \\
\text { mana-mana. "Indonesian Chinesedead bodies } \\
\text { were everywhere"(Putri Cina, 107).. } \\
\text { opa saya dibunuholeh penduduk setempat } \\
\text { dengan cara yang amat sadis. "My grand } \\
\text { father was sadistically killed by the local } \\
\text { citizens" (Miss Lu, 149). } \\
\text { Cina, kamu! Kamu harus mati di tangan } \\
\text { kami. "You are Chinese! You must die in our } \\
\text { hands" (Putri Cina, 150) }\end{array}$ & $\begin{array}{l}\text { The mass murder of } \\
\text { the Dutch period; the } \\
\text { mass murder of post- } \\
\text { G30-S (Movement of } \\
\text { September 30); Mass } \\
\text { murder in Trategdy of } \\
\text { May } 1998 \text {. }\end{array}$ \\
\hline
\end{tabular}

In connection with the segregation, the above data show that the Dutch colonizers were the makers of the segregated conditions, with the aim of separating the Indonesian Chinese community from the indigenous communities. This segregation was not just physical separation (in the case of separating residences) but it was also social one (in the case of positioning Indonesian Chinese community on the higher level position than the indigenous peoples). In the present context, the Indonesian Chinesecommunity aregetting a negative stigma as an exclusive community.

In connection with the violence, the above data serve the meanings that thetragedy of May 1998.This tragedy was triggered by national economic crisis.Toward the crisis, mass demonstration that was initially held peacefully, turning into a huge riot and as a consequence many people died. When a mass demonstration turns into a riot, Indonesian Chinese women: (1) were in the condition of great fear, and (2) were subjected to rape, and (3) many of them were brutally murdered. In the riot, demonstration mass, that had been provoked, destructed whatever belonging to the Indonesian Chinese, looted, robbed, and burned their properties. This makes the Indonesian Chinesebe in a state of extraordinary fear. The state of the fear is influenced by the past experience, namely: mass riot turning into the tragedy.

In connection with the act of expulsion, the above data show that the expulsion of IndonesianChinesecommunity took place since the Dutch colonial era. In the Dutch period, although under the pressure, the Chinese had the strong mentality, high work ethic, and unyielding attitude. The condition was regarded as harming the interests of the Netherlands, thus Dutch colonial expelled them from Batavia and returned them to the land of China. In the reign of the Old Order, Indonesian Chinese traders were not allowed to trade in the rural areas and subdistricts. They should move to trade in big cities. In the period of leading up to the collapse of the New Order, a number of Indonesian Chinese preferred to leave Indonesia and live abroad because of unsafe condition.

The above data also show the mass killings agiant IndonesianChineseand the followers of the Indonesian Communist Party in Batavia occurring in the Dutch colonial period, in the Tragedy of $30^{\text {th }}$ September, 1965 , and the Tragedy of May 1998. Mass killings against them in the Dutch colonial period because they were considered to launchrebellion; the mass killings in the Tragedy of $30^{\text {th }}$ September, because they were considered to be involved in the rebellion conducted by the Communist Party of Indonesia; and massacres in the Tragedy of May 1998 because they were considered to be the prime cause of the monetary crisis. 


\section{Religous Behavior}

Religious behavior of Indonesian Chineseis presented in the following table.

Table 13. Religious behavior

\begin{tabular}{|l|l|l|}
\hline $\begin{array}{l}\text { Behavioral } \\
\text { aspects }\end{array}$ & Behaviors in the novel & Behaviors represented \\
\hline & $\begin{array}{l}\text { Tidak mudah menjalankan ibadat mereka di } \\
\text { kelenteng-kelenteng. "It was hard form them to } \\
\text { pray in the temple" (Putri Cina, 110). }\end{array}$ & $\begin{array}{l}\text { They had problems in the } \\
\text { praying in their traditional } \\
\text { religion. }\end{array}$ \\
\cline { 2 - 3 } & $\begin{array}{l}\text { Tidak ada libur Imlek pada masa itu, masa } \\
\text { pemerintahan Soeharto. "No holiday at that } \\
\text { time, in the era of Soeharto's Government" } \\
\text { (Dimsum Terakhir, 60). }\end{array}$ & \\
\hline
\end{tabular}

In the religious life, Indonesian Chinese are not only the followers of their traditional religion. Other than the followers of Confucius, Budhism, and Taosism, some of them are Moslem, Christian, and Hindu. Their traditional religion was forbidden in the era of New Order Government. They had no problems if they are Moslem, Chistian, Budhist, or Hindu. As a consequences, they faced my problems in implementing their prayer and in celebrating the Chinese New Year.

\section{CONCLUSION}

The research findings show that personallyChinesegroup: (1) are well-known to have a high working spirit, (2) are proud to be an ethnic having high level of culture, (3) are hard not implement their tradition as heritage of their eldest generation, so that they have some problems to conduct the total assimilation, (4) have a view to be superior, and (5) have ambivalent, mimicry and hybrid behaviors. Socially, Chinese's social behaviors are as follows. Firstly, in marriage, Lely's parents have a consideration to determine characteristics of a future husband. Secondly, in family, Lely's family positioned women in the second class. Thirdly, in business, Lely's family have high integrity in relation to business family. Fourthly, in politics, Lely's family tend to passively behave. Fifthly, assimilation of Indonesian Chinese through inter-marriage can be classified into three kinds of behavior : (1)to conduct inter-marriage, (2) to avoid inter-marriage, and (3) (the native) ignore inter-marriage. Sixthly, some stereotypes attached to them are, that they are (1) exclusive because of living in pecinan, (2) judged as communists or closed to communism, (3) having high working spirit, (4) they ignore a total assimilation, (5) not nationalists, (6) regarded asforeigners, and (7) determined as the rich people. Seventhly, Indonesian Chinese live under the domination of mainstream group. Their inferiority causes them to face some prejudice, discrimination, segregation, expatriation, and to become the object of violence, pillage, robbery, murder, and rape. The religious behavior represented in Indonesia novels: firstly, Raden Patah involved in the spreading of Islam; secondly, Putri Cina practiced the religious tradition of Chinese religious heritage; thirdly, the conversion of the Chinese ancestral religion to Christianity in the Nung Antasana's family.

As represented in some Indonesian novels, the author comes to conclusion in relation to the personal and social behaviors belonging to Indonesian Chinese. Personally, Indonesian Chinese are that they : (1) have a high work ethic, (2) havea seperior feeling, (3) have apolitical, ambivalent, mimicry and hibrid attitudes; and socially, they(1) have some criteria in choosing future husband for their daughters, (2) regard women from the viewpoint of the natural law (Yin-Yang), (3) have high integrity toward their family or community, (4) tend to be passive in political affairs, (4) (some) conduct intermarriage with the native people, (5) are given negative stereotypes, and (6) live in the dominative condition based on which they become the target of prejudice, discrimination, segregation, expulsion, violent acts, robbery, murder, and rape (for women). Personally, Indonesian Chinese are those who face the hard life; socially, they live in the dominative condition; and religiously, they do not have a freedom to pray according to their traditional religion. At last, it can be said that Indonesian Chinese' behaviors are represented in the hard life.

\section{REFERENCES}

[1] Chusjairi, Juni Alfiah. 2005. Konstruksi Identitas Etnik Cina Pasca Orde Baru Melalui Media : Studi Pemaknaan Film Cina : Wo Si Ni Indonesia, Jangan Pangil Aku Cina dan Ca-Bau-Kan. Jakarta : Universitas Indonesia.

[2] Clara NG. 2012. Dimsum Terakhir. Cetakan ketiga. Jakarta: Gramedia Pustaka Utama.

[3] Coppel, Charles A. 1983. Indonesian Chinese in Crisis. Oxford New York:Oxford University Press.

[4] Faruk, dkk. 2000. Perlawanan atas Diskriminasi Rasial-Etnik, Konteks Sosial-Ideologis Kritik Sastra Peranakan Tionghoa. Magelang: Indonesia Tera.

[5] Hall, Stuart. 1997. Representation: Representations and Signifying Practices.London : SAGE Publications. 
[6] Hermawan, Sainul. 2005. Tionghoa dalam Sastra Indonesia. Yogyakarta : IRCiSoD

[7] Ibrahim, Ratna Indraswari, 2011. Pecinan. Yogyakarta : Laksana

[8] Kurniati, Christina. 2013. Putri Cina Dan Gundik Orang Lewi Suatu Upaya Cross-textual Interpretation Terhadap Dinamika Kekerasan Yang Dialami Oleh Perempuan Asing Sebagai Warga Kelas Dua .Salatiga UKSW.

[9] Lembahmata, Pralampita. 2011. Bonsai, Hikayat Satu Keluarga Cina Benteng. Jakarta : PT Gramedia Pustaka Utama.

[10] Mulyono, Edi (dkk). 2012. Belajar Hermeneutika. Jogjakarta : IRCiSoD

[11] Pranoto, Naning. 2003. Miss Lu, Putri Cina Yang Terjebak Konflik Etnik dan Politik. Jakarta : Grasindo.

[12] Recoeur, Paul.1981. Hermeneutics and Human Sciences. Cambridge : Cambridge University Press).

[13] Recoeur, Paul, 2012. Teori Interpretasi, Memahami Teks, Penafsiran, dan Metodologinya. Yogyakarta : IRCiSod

[14] Rukardi. 2010. "Tionghoa dan Subversi Sastra Melayu-Rendah" http://media-sastranusantara.blogspot.com/2010/03/ accessed at 2 June 2013

[15] Salmon, Claudine, 2010. Sastra Indonesia Awal, Kontribusi Orang Tionghoa. Jakarta: Kepustakaan Populer Gramedia.

[16] Sindhunata, 2007. Putri Cina. Jakarta : PT Gramedia Pustaka Utama.

[17] Soyomukti, Nurani. 2012. Soekarno \& Cina. Jogyakarta : Garasi.

[18] Sugiri, Eddy. 2003. Perspektif Budaya Perubahan Nama Diri bagi

[19] WNI Keturunan Tionghoa di Wilayah Pemerintah Kota Surabaya, in Jurnal BAHASA DAN SENI, Tahun 31, Nomor 1, Februari 2003. Malang : UM

[20] Sumardjo, Jakob. 2004. Kesusastraan Melayu-Rendah Masa Awal. Yogyakarta : Galang Press.

[21] Suryadinata, Leo. 2002. Negara dan Etis Tionghoa : Kasus Indonesia.Jakarta : LP3ES.

[22] Sylado, Remy. 1999. Ca-bau-kan. Novel. Jakarta : KPG

[23] Tjeng, Lie Tek. 1995. "Konfusianisme dan Modernisasi”.Yogyakarta:Penerbit INTERFIDIE.

[24] Vasanty, Puspa. 1983. "Kebudayaan Orang Tionghoa di Indonesia” dalam Koentjaraningrat. 1983. Manusia dan Kebudayaan di Indonesia.Jakarta : Djambatan.

Winter, Rainer. "Cultural Studies" dalam Flick, Uwe. 2014.The SAGE Handbook of

[25] Qualitative Data Analysis. City Road-London : SAGE Publications Ltd

[26] Woodrich, Chistoper Allen. 2011. Pengaruh Tragedi 1998 Dalam Novel Putri Cina. Yogyakarta : Universitas Sanatha Darma.

[27] Wulandari, F.R. 2011. Perilaku Ekonomi Etnis Cina di Indonesia Sejak Tahun 1930-an, dalam http://web.budaya-tionghoa.net

Fatchul Mu'in is a Lecturer inHumanities at Universitas Lambung Mangkurat, Banjarmasin, South Kalimantan, Indonesia. He earned his Master of Humanities from Universitas Gadjah Mada, Yogyakarta, Indonesia and Doctor degree from Universitas Negeri Malang, East Java, Indonesia. 